\title{
Maternal Origin of 'Tarokaja' and Other Wabisuke Camellia Cultivars Indicated by Chloroplast DNA Variation
}

\author{
Natsu Tanikawa ${ }^{1,2 *}$, Takashi Onozaki ${ }^{1}$, Masayoshi Nakayama ${ }^{1,2}$ and Michio Shibata ${ }^{1 * *}$ \\ ${ }^{1}$ National Institute of Floricultural Science, Tsukuba 305-8519, Japan \\ ${ }^{2}$ Graduate School of Life and Environmental Sciences, University of Tsukuba, Tsukuba 305-8572, Japan
}

\begin{abstract}
The wabisuke camellia 'Tarokaja' is a very old cultivar of unknown origin. Based on morphological properties, it is thought to be an interspecific hybrid between Camellia japonica and an unidentified species from continental China. We analyzed chloroplast DNA from members of the genus Camellia to trace the maternal origin of 'Tarokaja'. Polymerase chain reaction-restriction fragment length polymorphism (PCR-RFLP) analysis of the atpI-atpH spacer region using 57 progeny derived from 17 interspecific crosses confirmed that chloroplast DNA is inherited maternally in the genus Camellia. Based on PCR-RFLP and sequence analyses of the atpI-atpH region and referring to knowledge about morphological properties, we concluded that the maternal origin of 'Tarokaja' is a Chinese native species $C$. pitardii var. pitardii. Wabisuke camellia cultivars are classified into two groups. One group of wabisuke camellia cultivars is thought to be derived from crosses between 'Tarokaja' and $C$. japonica. Since most of them had a 'Tarokaja'-type single-base in the atpI-atpH region, it was confirmed that these wabisuke cultivars are descended from 'Tarokaja'. It is likely that 'Hime-wabisuke', 'Kocho-wabisuke', and 'Sukiya', which had a $C$. japonica-type single-base, are progeny descended from 'Tarokaja' with $C$. japonica as the maternal ancestor. Another group of wabisuke camellia cultivars is thought to be derived from $C$. japonica by mutation, and all but one of these had a $C$.japonica-type single-base. The exception, 'Kibi', had a 'Tarokaja'-type singlebase, so that 'Kibi' is inferred to be descended from 'Tarokaja'.
\end{abstract}

Key Words: Camellia pitardii var. pitardii, Camellia uraku 'Tarokaja', chloroplast DNA, maternal origin, wabisuke camellia.

\section{Introduction}

There is a group of horticultural Camellia cultivars called the wabisuke camellias, which are distinguished by their atrophied and abortive androecia. They also have the characteristics of early flowering, small single flowers, sterile pistils, and no seed formation (Kirino, 1986). Written records of wabisuke camellia cultivars such as 'Tarokaja' (Fig. 1a) and 'Kocho-wabisuke' go back to the middle of the Edo period (1603-1867) (Tanaka et al., 2001). Kitamura (1952) reported that there are wabisuke camellias in temples in Kyoto, the old capital of Japan, which are thought to have been

Received; February 28, 2009. Accepted; June 30, 2009.

A part of this work was presented at the 2004 Spring Meeting of the Japanese Society for Horticultural Science.

* Corresponding author (E-mail: natsu@affrc.go.jp).

** Present address: Ministry of Agriculture, Forestry and Fisheries, Chiyoda-ku, Tokyo 100-8950, Japan. planted 350-400 years ago. These observations suggest that the wabisuke camellias were generated more than 400 years ago. They have taken root in Japanese traditional culture and been loved for a long time in Japan.

Wabisuke camellias are classified into two groups (Kirino, 1986). One group is thought to be derived from mutations in the Japanese native species Camellia japonica $\mathrm{L}$. These camellias generally have red flowers, a glabrous ovary, and a leaf shape that are similar to those of C.japonica. Members of the other group of wabisuke camellias have elliptical acuminate leaves. Most of these camellias have a pubescent ovary, which is not a characteristic of C. japonica. Members of this second group are thought to be derived from a cross between 'Tarokaja' and C. japonica, because 'Tarokaja' is a very old wabisuke camellia cultivar with a pubescent ovary and imperfect fertility, which can produce small numbers of pollen grains and seeds exceptionally among wabisuke camellias (Kirino, 1986; Tanaka et al., 2001). 
(a)

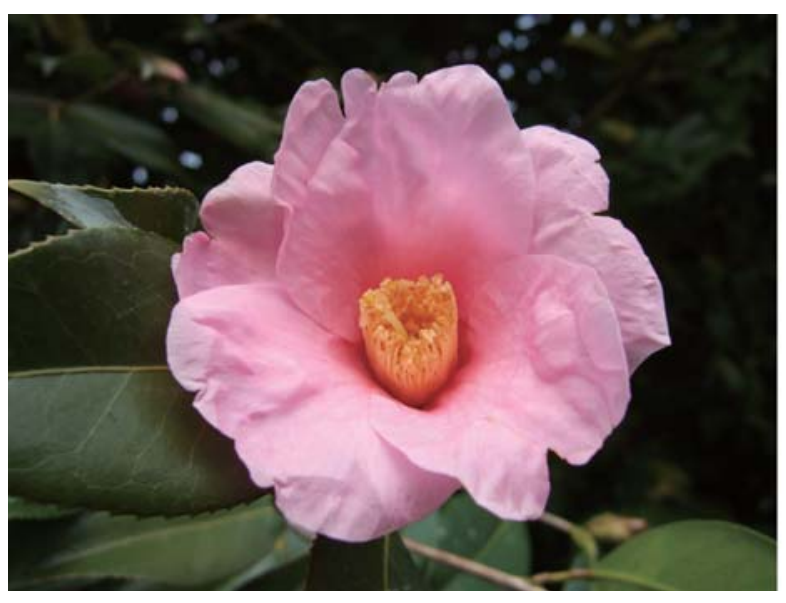

(b)

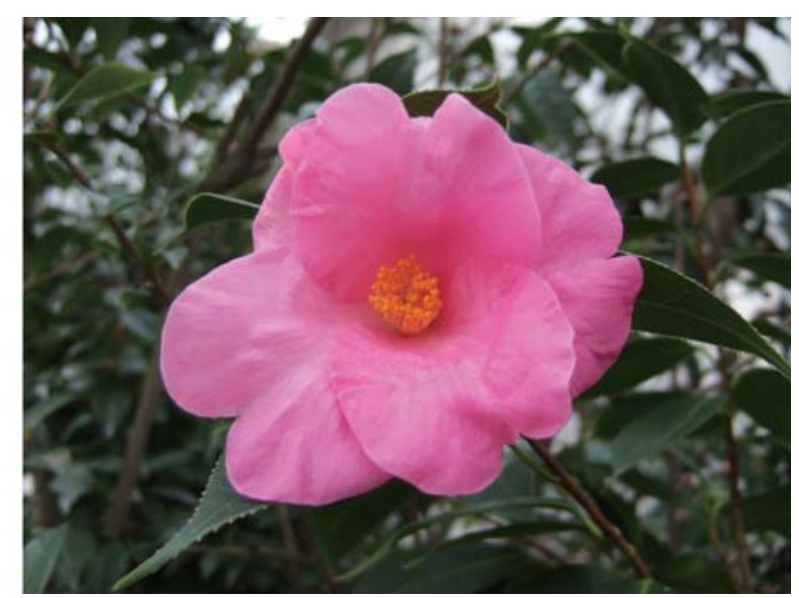

Fig. 1. Flowers of 'Tarokaja' (a) and C. pitardii var. pitardii (b).

It was verified by hybridization that the wabisuke camellias with atrophied androecia were derived from a cross between 'Tarokaja' and C. japonica (Kirino, 1986). The origin of 'Tarokaja' remains to be established, and an answer to this question is needed to shed light on the ancestry of the latter group of cultivars.

The origin of 'Tarokaja' has been of interest to researchers for a long time. Its flowering period is from December to April, and the flower color is purplish pink. The leaves of 'Tarokaja' are elliptical, acuminate, and serrulate. Camellia cultivars generally have little scent, but 'Tarokaja' is fragrant. Kitamura (1952) treated 'Tarokaja' as a species, C. uraku Kitamura. However, it is known only as a cultivated plant, and its geographical origins are unknown (Chang and Bartholomew, 1984; Gao et al., 2005; Sealy, 1958). Because the Japanese species C.japonica does not have a pubescent ovary, some researchers have speculated that 'Tarokaja' is derived from a species from continental China. Over the past 100 years, various Chinese species have been proposed as the origin of 'Tarokaja' and other wabisuke camellias. These include C.reticulata Lindl., C. cuspidata (Kochs) Wright, C.rosaeflora Hook., C. sinensis (L.) O. Kuntze, C. saluenensis Stapf ex Bean, C. kissi Wall., and C. pitardii Cohen Stuart var. pitardii (Kirino, 1986; Kitamura, 1970; Makino, 1910; Nakai, 1950; Tanaka et al., 2001). Based on morphological properties it seems most likely that 'Tarokaja' is an interspecific hybrid between C. japonica and C. pitardii var. pitardii (Fig. 1b) (Kirino, 1986; Tanaka et al., 2001).

Chloroplast DNA shows maternal inheritance in most flowering plants. It does not undergo recombination, and has a slow rate of evolution (Palmer, 1987). Therefore, chloroplast DNA is a useful tool for tracing maternal ancestors. We previously used the polymerase chain reaction-restriction fragment length polymorphism (PCR-RFLP) method to analyze chloroplast DNA in the genus Camellia. We found that 8 PCR-RFLP patterns (800a, 800b, 800c, 1200a, 1200b, 1200c, 1200d, and 1200e) were detected when the spacer region between $a t p \mathrm{I}$ and $a t p \mathrm{H}$ was amplified by PCR and digested using the restriction enzyme TaqI (Tanikawa et al., 2008). Sequence analysis of the atpI-atpH region showed variations that can be used to distinguish between the species. In this study, we conducted PCR-RFLP analysis of the atpI-atpH region from 57 progeny derived from 17 interspecific crosses of the genus Camellia to confirm that chloroplast DNA in the genus Camellia is maternally inherited. We sought to identify the maternal origin of 'Tarokaja' by comparing PCR-RFLP patterns and variations in the atpI-atpH region of 'Tarokaja' and a variety of Camellia species. We also tried to trace the origins of other wabisuke camellia cultivars and related cultivars using the chloroplast DNA variations.

\section{Materials and Methods}

\section{Plant materials}

We examined the parental lines and 57 progeny derived from 17 interspecific crosses of Camellia (Table 1). We also compared 'Tarokaja' with 23 accessions derived from 20 species of the genus Camellia that showed the 1200a PCR-RFLP pattern in our previous report (Tanikawa et al., 2008) (Table 2). Nine C.japonica cultivars, 26 wabisuke cultivars, and the related cultivars 'Funatsu', 'Kaga-wabisuke', and 'Seiobo' were also analyzed (Table 3). All camellia plants were grown at National Institute of Floricultural Science (NIFS).

\section{DNA extraction}

Young leaf samples were ground to a fine powder in liquid nitrogen using a mortar and pestle. Total DNA, including chloroplast DNA, was extracted using the ISOPLANT II kit (Nippon Gene Co., Ltd., Tokyo, Japan). The extracted DNA samples were purified using CHROMA SPIN + TE-1000 columns (Clontech Laboratories, Inc., Mountain View, CA, USA). 
Table 1. Inheritance of chloroplast DNA in interspecific hybrids of the genus Camellia. PCR-RFLP analysis was conducted by digestion of the PCR-amplified atpI-atpH region with TaqI. The PCR-RFLP patterns of C. saluenensis, C. fraterna Hance, C. oleifera Abel, C. sasanqua Thunb., C. granthamiana Sealy, C. brevistyla (Hay.) Cohen Stuart, C. lutchuensis Ito, C. nokoensis Hay., and C. rosaeflora were investigated in our previous study (Tanikawa et al., 2008).

\begin{tabular}{|c|c|c|c|c|}
\hline \multirow[t]{2}{*}{ Cross; Parent 우 $\times \diamond^{\nearrow}$} & \multicolumn{2}{|c|}{ PCR-RFLP pattern of parents } & \multicolumn{2}{|c|}{$\begin{array}{l}\text { Numbers of progeny with } \\
\text { PCR-RFLP pattern }\end{array}$} \\
\hline & Maternal & Paternal & Maternal & Paternal \\
\hline C. japonica 'Aki-no-yama' $\times$ C. saluenensis & $1200 \mathrm{~d}$ & $1200 \mathrm{c}$ & 2 & 0 \\
\hline C. japonica 'Arukawa' $\times$ C. saluenensis & $1200 \mathrm{a}$ & $1200 \mathrm{c}$ & 3 & 0 \\
\hline C. japonica 'Kokuryu' $\times$ C. saluenensis & $1200 \mathrm{a}$ & $1200 \mathrm{c}$ & 2 & 0 \\
\hline C. japonica 'Komomiji' $\times$ C. saluenensis & $1200 \mathrm{a}$ & $1200 \mathrm{c}$ & 1 & 0 \\
\hline C. japonica 'Kon-wabisuke' $\times$ C. saluenensis & $1200 \mathrm{a}$ & $1200 \mathrm{c}$ & 3 & 0 \\
\hline C. japonica 'Kuro-tsubaki' $\times$ C. saluenensis & $1200 \mathrm{a}$ & $1200 \mathrm{c}$ & 4 & 0 \\
\hline C. japonica 'Miyakodori' $\times$ C. saluenensis & $1200 \mathrm{a}$ & $1200 \mathrm{c}$ & 3 & 0 \\
\hline C. japonica 'Rasenzome' $\times$ C. saluenensis & $1200 \mathrm{a}$ & $1200 \mathrm{c}$ & 1 & 0 \\
\hline C. japonica 'Suzukayama' $\times$ C. saluenensis & $1200 \mathrm{a}$ & $1200 \mathrm{c}$ & 1 & 0 \\
\hline C. japonica 'Tokijiro' $\times$ C. saluenensis & $1200 \mathrm{a}$ & $1200 \mathrm{c}$ & 2 & 0 \\
\hline C. japonica 'Kon-wabisuke' $\times$ C. fraterna & $1200 \mathrm{a}$ & $1200 \mathrm{c}$ & 4 & 0 \\
\hline C. japonica 'Waka-no-ura' $\times$ C. fraterna & $1200 \mathrm{a}$ & $1200 \mathrm{c}$ & 2 & 0 \\
\hline C. hiemalis 'Tachikantsubaki' $\times$ C. oleifera & $800 \mathrm{~b}$ & $1200 \mathrm{a}$ & 13 & 0 \\
\hline C. sasanqua $\times$ C. granthamiana & $800 \mathrm{~b}$ & $1200 \mathrm{e}$ & 3 & 0 \\
\hline C. brevistyla $\times$ C. oleifera & $1200 \mathrm{~b}$ & $1200 \mathrm{a}$ & 3 & 0 \\
\hline C. lutchuensis $\times$ C. nokoensis & $1200 \mathrm{a}$ & $1200 \mathrm{c}$ & 4 & 0 \\
\hline C. rosaeflora $\times$ C. fraterna & $1200 \mathrm{a}$ & $1200 \mathrm{c}$ & 6 & 0 \\
\hline
\end{tabular}

Table 2. Single nucleotide variations at the 88 th position from the $3^{\prime}$ end of the atp $\mathrm{I}-a t p \mathrm{H}$ region, in species and varieties of the genus Camellia possessing the 1200a PCR-RFLP pattern.

\begin{tabular}{|c|c|c|c|}
\hline Species & NIFS No. & $\begin{array}{l}\text { Nucleotide at the } 88 \text { th } \\
\text { position }\end{array}$ & DDBJ Accession No. \\
\hline C. uraku 'Tarokaja' & 180 & $\mathrm{C}$ & AB443610 \\
\hline C. japonica 'Chinshin' & 622 & A & $\mathrm{AB} 364653^{\mathrm{z}}$ \\
\hline C. amplexicaulis & 1215 & A & $\mathrm{AB} 364664^{\mathrm{z}}$ \\
\hline C. caudata & 913 & A or deletion of $5 \mathrm{bp}$ & AB443617 \\
\hline C. chrysantha & 565 & A & \\
\hline C. chrysantha var. microcarpa & 569 & A & \\
\hline C. crapnelliana & 914 & $\mathrm{C}$ & AB443611 \\
\hline C. forrestii & 1207 & A or deletion of $5 \mathrm{bp}$ & \\
\hline C. furfuracea & 1219 & $\mathrm{~A}$ & AB443614 \\
\hline C. gigantocarpa & 917 & A & AB443612 \\
\hline C. hongkongensis & 918 & A & $\mathrm{AB} 364665^{\mathrm{z}}$ \\
\hline C. japonica var. hozanensis & 755 & A & \\
\hline C. japonica var. hozanensis & 1097 & A & \\
\hline C. japonica var. macrocarpa & 1069 & A & \\
\hline C. lutchuensis & 951 & A & $\mathrm{AB} 364668^{\mathrm{z}}$ \\
\hline C. lutchuensis & 1118 & A & $\mathrm{AB} 364669^{\mathrm{z}}$ \\
\hline C. octopetala & 1193 & A & AB443613 \\
\hline C. oleifera & 760 & A & $\mathrm{AB} 364666^{\mathrm{z}}$ \\
\hline C. oleifera & 1115 & A & $\mathrm{AB} 364667^{\mathrm{z}}$ \\
\hline C. pitardii var. pitardii & 1218 & $\mathrm{C}$ & AB443616 \\
\hline C. polyodonta & 1004 & $\mathrm{C}$ & AB443615 \\
\hline C. rosaeflora & 1121 & A & \\
\hline C. sinensis 'Toyoka' & 1221 & A & \\
\hline C. taliensis & 925 & A & $\mathrm{AB} 364663^{\mathrm{z}}$ \\
\hline
\end{tabular}

${ }^{\mathrm{z}}$ Sequences analyzed in our previous report (Tanikawa et al., 2008). 
Table 3. Single nucleotide variations at the 88th position from the $3^{\prime}$ end of the atpI-atpH region in C.japonica cultivars, wabisuke cultivars of 'Tarokaja' origin, wabisuke cultivars derived from mutations in C.japonica, and in the related cultivars 'Funatsu', 'Kaga-wabisuke', and 'Seiobo'.

\begin{tabular}{|c|c|c|c|c|c|c|c|}
\hline \multicolumn{2}{|c|}{ C. japonica cultivars } & \multicolumn{2}{|l|}{$\begin{array}{l}\text { Wabisuke cultivars of } \\
\text { 'Tarokaja' origin }\end{array}$} & \multicolumn{2}{|c|}{$\begin{array}{l}\text { Wabisuke cultivars derived from } \\
\text { C. japonica mutations }\end{array}$} & \multicolumn{2}{|c|}{ Related cultivars } \\
\hline 'Fumon-in' & A & 'Beni-wabisuke' & $\mathrm{C}$ & 'Ichiko-wabisuke' & A & 'Funatsu' & A \\
\hline 'Fusen-in-aka-yabu' & A & 'Eishoji-wabisuke' & $\mathrm{C}$ & 'Iyo-wabishin' & A & 'Kaga-wabisuke' & $\mathrm{C}$ \\
\hline 'Inzen' & A & 'Fukurin-wabisuke' & $\mathrm{C}$ & 'Kibi' & $\mathrm{C}$ & 'Seiobo' & $\mathrm{C}$ \\
\hline 'Mariasama' & A & 'Gomangoku' & $\mathrm{C}$ & 'Murage' & A & & \\
\hline 'Mitsuhime' & A & 'Hime-wabisuke' & $\mathrm{A}$ & 'Sado-wabisuke' & A & & \\
\hline 'Miyake-chidori' & A & 'Hina-wabisuke' & $\mathrm{C}$ & 'Sayo-wabisuke' & A & & \\
\hline 'Miyakodori' & A & 'Kanzaki-aka-wabisuke' & $\mathrm{C}$ & 'Sumi-no-hikari' & A & & \\
\hline 'Shirayuri' & $\mathrm{A}$ & 'Kocho-wabisuke' & $\mathrm{A}$ & 'Tenrinji-gakko' & A & & \\
\hline \multirow[t]{10}{*}{ 'Tomuro' } & A & 'Mikawa-sukiya' & $\mathrm{C}$ & & & & \\
\hline & & 'Otohime' & $\mathrm{C}$ & & & & \\
\hline & & 'Owari-wabisuke' & $\mathrm{C}$ & & & & \\
\hline & & 'Sagami-wabisuke' & $\mathrm{C}$ & & & & \\
\hline & & 'Shibenashi-wabisuke' & $\mathrm{C}$ & & & & \\
\hline & & 'Shibori-wabisuke' & $\mathrm{C}$ & & & & \\
\hline & & 'Shiro-wabisuke' & $\mathrm{C}$ & & & & \\
\hline & & 'Showa-wabisuke' & $\mathrm{C}$ & & & & \\
\hline & & 'Sukiya' & A & & & & \\
\hline & & 'Yutaka-wabisuke' & $\mathrm{A}$ & & & & \\
\hline
\end{tabular}

\section{PCR-RFLP analysis}

The primer sequences used for PCR amplification of the chloroplast DNA atpI-atpH region of most accessions were 5'-CCGCAGCTTATATAGGCGAA-3' and 5'TTGACCAACTCCAGGTCCAA-3' (Tsumura et al., 1996). The primers 5'-TGGAGGGCCATCATTGACTA-3' and 5'-TGATAAGTTCCTCGCACCAA-3' were used for C. caudata Wall. (NIFS No. 913) (Tanikawa et al., 2008). Each PCR reaction was carried out in a $20 \mu \mathrm{L}$ volume containing $40 \mathrm{ng}$ of template DNA, 3 pmol of each primer, $0.2 \mathrm{mM}$ of each dNTP, 1 unit of Ex Taq DNA polymerase (Takara Bio Inc., Shiga, Japan) and $2 \mu \mathrm{L}$ of $10 \times$ buffer for Ex Taq. The amplifications began with $94^{\circ} \mathrm{C}$ for $30 \mathrm{~s}$ for the initial denaturations, followed by 35 cycles of $94^{\circ} \mathrm{C}$ for $30 \mathrm{~s}, 60^{\circ} \mathrm{C}$ for $2 \mathrm{~min}$, and $72^{\circ} \mathrm{C}$ for $3 \mathrm{~min}$, with a final 7 -min incubation at $72^{\circ} \mathrm{C}$. To determine the sizes of the amplified fragments, $5 \mu \mathrm{L}$ of the PCR products were electrophoresed on $2 \%$ agarose gels (SeaKem GTG Agarose, Lonza Walkersville, Inc., Walkersville, MD, USA) containing ethidium bromide. The PCR products were also digested with the TaqI restriction enzyme and the digest fragments were separated by electrophoresis in $4 \%$ agarose gels containing ethidium bromide. DNA fragments were observed in the gels under UV light.

\section{Cloning and Sequencing of the atpI-atpH region}

The PCR amplified atpI-atpH regions of 'Tarokaja' (NIFS No. 180), C. crapnelliana Tutch. (NIFS No. 914), C. gigantocarpa $\mathrm{Hu}$ et T. C. Huang (NIFS No. 917), C. octopetala Hu (NIFS No. 1193), C. furfuracea (Merr.) Cohen Stuart (NIFS No. 1219), C. polyodonta How ex
$\mathrm{Hu}$ (NIFS No. 1004), C. pitardii var. pitardii (NIFS No. 1218), and C. caudata (NIFS No. 913) were cloned and sequenced. The PCR products were purified using the GFX PCR DNA and Gel Band Purification Kit (GE Healthcare UK Ltd., Buckinghamshire, UK). Purified DNA was ligated into the pT7Blue T-Vector (Novagen Inc., Madison, WI, USA) using a DNA Ligation Kit (Takara Bio Inc.) and then used to transform Escherichia coli strain JM109. The transformed cells were plated on LB agar plates containing X-gal, IPTG and ampicillin and incubated at $37^{\circ} \mathrm{C}$ overnight. White colonies were randomly selected and the presence of the desired insert was confirmed by PCR-RFLP. Three clones per transformation were selected. Plasmid DNA was isolated and purified using the QIAprep Spin Miniprep Kit (Qiagen GmbH, Hilden, Germany). Sequencing was performed using the BigDye Terminator Cycle Sequencing Kit (Applied Biosystems, Foster City, CA, USA). M13M4 and M13RV primers were used to sequence each clone from both directions. The sequences were analyzed using the DNASIS V3.7 program (Hitachi Software Engineering Co., Ltd., Tokyo, Japan). The determined sequence of the $a t p \mathrm{I}-a t p \mathrm{H}$ region for each species was deposited in the DDBJ database (accession numbers AB443610-AB443617).

A single-base variation was found at the 88 th position from the $3^{\prime}$ end of the at $\mathrm{I}-a t p \mathrm{H}$ region, excluding the primer region. In order to easily detect this nucleotide variation in other accessions, PCR-amplified products of atpI-atpH region were sequenced directly from the $3^{\prime}$ end only, using the primer 5'-TTGACCAACTCCAGGT CCAA-3'. The PCR products were purified using the 
GFX PCR DNA and Gel Band Purification Kit. Sequence analyses were performed as described above.

\section{Results and Discussion}

PCR-RFLP patterns were categorized according to our previous report; the PCR amplifications resulted in two major bands of approximately $800 \mathrm{bp}$ and $1200 \mathrm{bp}$ and then TaqI digestion of the PCR products resulted in 3 different band patterns derived from the $800 \mathrm{bp}$ fragment $(800 \mathrm{a}, 800 \mathrm{~b}$, and $800 \mathrm{c})$ and 5 patterns derived from the $1200 \mathrm{bp}$ fragment $(1200 \mathrm{a}, 1200 \mathrm{~b}, 1200 \mathrm{c}, 1200 \mathrm{~d}$, and 1200e) (Tanikawa et al., 2008). To investigate the inheritance of chloroplast DNA in the genus Camellia, the PCR-RFLP analysis was conducted using a total of 57 progeny from 17 crosses between parents showing different PCR-RFLP patterns. All the progeny exhibited the same PCR-RFLP patterns as the maternal parents, thus confirming that the chloroplast DNA is maternally inherited in the genus Camellia, as it is in most angiosperms (Table 1).

We next performed a PCR-RFLP analysis to trace the maternal lineage of 'Tarokaja'. 'Tarokaja' is thought to have originated from a hybrid between $C$.japonica and a species from continental China. The atpI-atpH PCRRFLP pattern of 'Tarokaja' was of the type 1200a. Our previous work indicated that $C$.japonica accessions are of the types 1200a or 1200d (Tanikawa et al., 2008). Therefore, we sequenced the atp $\mathrm{I}-a t p \mathrm{H}$ region of 'Tarokaja' (AB443610) and compared it with that of a 1200a type of C.japonica (AB364653), in order to identify additional nucleotide variations that might be used to distinguish between 'Tarojaka' and C.japonica. Two sequences of multiple adenines in the at $p \mathrm{I}-a t p \mathrm{H}$ region were excluded from the comparison because we could not determine the exact numbers of adenines in these sequences (Tanikawa et al., 2008). A single nucleotide polymorphism was identified at the 88th position from the 3 ' end of atp $\mathrm{I}-a t p \mathrm{H}$ region (excluding primer sequence) (Fig. 2). This base was adenine in C.japonica and cytosine in 'Tarokaja'. This clearly indicated that C.japonica is not a maternal ancestor of 'Tarokaja', and that another species showing the 1200a PCR-RFLP pattern must be its maternal ancestor.

In our previous study we found that 20 of the 49 Camellia species had the 1200a pattern, including C.japonica (Tanikawa et al., 2008). We therefore sequenced the $3^{\prime}$ end of the atpI-atp $\mathrm{H}$ region in 22 accessions representing the other 19 species, and identified the base at the 88th position from the 3 ' end in each case (Table 2). Three species, C. pitardii var. pitardii (NIFS No. 1218), C. crapnelliana (NIFS No. 914), and C. polyodonta (NIFS No. 1004) had a cytosine

1 TCCATGGAgGGCCATCATTGACTAGTTTTCGAAATAGTCTCTAGCCCAAGGTAATCTATTTAGgGATATAAATATACAAATACGTTATATACGATCTAG 100

101 AgTAATAACAAAAAAGATTAGGATATTAGAGAATTGTAAAAAAAAAAAAAGGAAGAGATCTAAAAGATCTTTTTCCTAAAATTCCTGTTTGGTCTACTT 200

201 ATATCATACCTCTCCTCAATGAATATTCTATTTCTATTGTTCAGTCAATCCTTAAATATTAGGAGTCATAATTTGAATAAGAATTCTTGTGGTATATGTT 300

301 TATGgCGTATGATTAAATAAAAATAAAAAAGTATGTTCTATAGAACGATTACCCGCTTCAGTTGAATtTTATTCAATTCAACGATTGACCAAAAGAAATT 400

b

401 TTTAATAAATAATAAATTGCATGAACTTAGATCAATCAAATAATGATATTTCTATGCAATGATTCGGCCTAATCAATTTGTCCATTTCGATTCTATCCAT 500

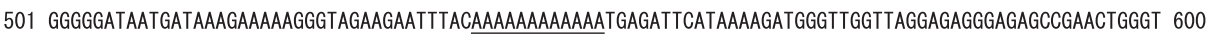

601 CTATGTAATTTAATTGCTATAAGTCAACTCTTGTAGTGTGGGTGTTTTGATGAATGATTCTAGAATCCGATTGAATCTAAGATGgGAATAGTTGGTTTAC 700

701 GTTATGGAAGAAAGACATGTATATGTGATATTAGATATTGACTTGACTAGTTAGATATATGAACTAAAATTATATCTAATTTGCTCTACTATTGTGAATT 800

801 TGGATGgGGATTCCAATAGAAATCCTTCGGTCTCGTTTGTGACTGTGAGTTGAATGAATAAACAAATGAAATCAAGAAAAAGATCGAAGAATTCAAAGAA 900

901 CGgtTCGgGACAAAGAATGgAagAACGAAAGTCGTATGgATTCACAAAGACTCTGTGGATAGAAGATATCGAAGTAGTTCTGATGATTCAATAATATTT 1000

1001 TGACTCCAATtTGAAGTTCTTAGTTACTTCGACTGGATGAATTTTAGGGATGGAATAATTACGTCATAATTCATTGGTTGATTGTATCATTAACCATTTT 1100

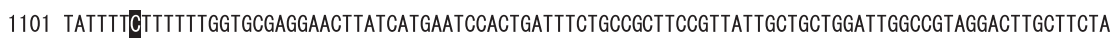

a

Fig. 2. The nucleotide sequence of the atpI-atpH region of 'Tarokaja' (Accession number AB443610). Black box a: the 88th position from the 3 ' end, b: the 355 th position from the 5 ' end where single-base substitution to thymine was detected in C.crapnelliana. Underlines show poly-A sequences where the exact numbers of adenines were not determined. 
at the 88th position, as did 'Tarokaja'. We then compared the whole nucleotide sequences of the at $\mathrm{I}-a t p \mathrm{H}$ regions in these 3 species and 'Tarokaja'. The sequences of C. pitardii var. pitardii (AB443616) and C.polyodonta (AB443615) were identical to that of 'Tarokaja', while a single nucleotide difference was found in the C. crapnelliana (AB443611) sequence when compared with that of 'Tarokaja'; the base of the 355th position from the 5 ' end was cytosine in 'Tarokaja', while the base was thymine in C. crapnelliana (Fig. 2).

Among the species that have been considered as candidates for the ancestor of 'Tarokaja', C. reticulata, C.cuspidata, C. saluenensis, and C.kissi showed the $1200 \mathrm{c}, 1200 \mathrm{c}, 1200 \mathrm{c}$, and $1200 \mathrm{e}$ PCR-RFLP patterns, respectively (Tanikawa et al., 2008). C. rosaeflora and C. sinensis showed the 1200a pattern, but their 88th nucleotide bases were adenine (Table 2). Of the two species with nucleotide sequences in the atpI-atpH region that are identical with that of 'Tarokaja', C. polyodonta has never been considered previously to be the ancestor. C. pitardii var. pitardii has a pubescent ovary and elliptical, acuminate, and serrulate leaves, which are morphological properties of 'Tarokaja' as well (Chang and Bartholomew, 1984; Gao et al., 2005; Sealy, 1958). Both 'Tarokaja' and C. pitardii var. pitardii have chromosome number of $2 \mathrm{n}=30$ (Gao et al., 2005; Kirino, 1986). We therefore conclude that C. pitardii var. pitardii is the maternal ancestor of 'Tarokaja'.

In order to clarify the origins of other wabisuke camellias, we investigated the PCR-RFLP patterns and sequenced the $3^{\prime}$ ends of the atpI-atpH regions of 38 cultivars. These included 18 wabisuke camellia cultivars that are thought to be progeny of 'Tarokaja', 8 wabisuke camellia cultivars that are thought to be generated from mutations of C.japonica, 9 C.japonica cultivars, and the related cultivars 'Funatsu', 'Kaga-wabisuke', and 'Seiobo'. All of them showed the 1200a PCR-RFLP pattern.

Of the 18 wabisuke camellia cultivars that are thought to be progeny of 'Tarokaja', 14 cultivars had a cytosine at the 88th position from the $3^{\prime}$ end of the atpI-atpH region, as did 'Tarokaja' (Table 3 ). This result supports the hypothesis that these wabisuke cultivars were generated with 'Tarokaja' as their ancestor. The exceptions were 'Hime-wabisuke', 'Kocho-wabisuke', 'Sukiya', and 'Yutaka-wabisuke'. 'Funatsu' was bred artificially using C.japonica as the seed parent and 'Tarokaja' as the pollen parent (Kirino, 1986). Although 'Funatsu' is descended from 'Tarokaja', its androecium and pistil are normal and it can form seeds. However, some progeny of 'Funatsu' are wabisuke type camellias with atrophied androecia (Kirino, 1986; Yokoyama and Kirino, 2005). 'Yutaka-wabisuke' was produced by natural pollination of 'Funatsu' (Yokoyama and Kirino, 2005). Therefore, the 88th base from 3' end of the atpI$a t p \mathrm{H}$ region in both 'Funatsu' and 'Yutaka-wabisuke' was adenine, as it was in C.japonica (Table 3). It is likely that 'Hime-wabisuke', 'Kocho-wabisuke', and 'Sukiya', which appear to be descended from 'Tarokaja' but have adenines at the 88th position (Table 3 ), are also progeny descended from 'Tarokaja' with C.japonica as the maternal ancestor, as it is for 'Yutaka-wabisuke'.

'Kaga-wabisuke' has the term 'wabisuke' in its cultivar name; however, it has a normal androecium and pistil, and it is fertile. Therefore 'Kaga-wabisuke' is not a wabisuke camellia in the strict sense of the word. However, based on its pubescent ovary, early flowering, flower color, and leaf shape, it is thought to be generated from 'Tarokaja' (Yokoyama and Kirino, 2005). The presence of a cytosine at the 88th position from the 3 ' end of the atpI-atpH region in 'Kaga-wabisuke' (Table 3) indicates that this cultivar was generated with 'Tarokaja' as a maternal ancestor. 'Seiobo' is known as an excellent camellia cultivar. It has very early-flowering and blooms from autumn onwards. Its androecium and pistil are normal. 'Kaga-wabisuke' is believed to be a parent of 'Seiobo' because they have some similar morphological features and they both came from Ishikawa Prefecture (Yokoyama and Kirino, 2005). We also found a cytosine at the 88th position in 'Seiobo' (Table 3), confirming that it is also of 'Tarokaja' lineage.

All of the C.japonica cultivars examined in this study had adenines at the 88th position from the 3 ' end of the $a t p \mathrm{I}-a t p \mathrm{H}$ region (Table 3 ). All but one of the wabisuke camellia cultivars that are thought to be generated from mutations of $C$.japonica also had adenines at that position (Table 3). The exception was 'Kibi', which, like 'Tarokaja', has a cytosine in that position (Table 3). The origin of 'Kibi' has been in question because it has a pubescent ovary (Kirino, 1986; Yokoyama and Kirino, 2005). Our results show that it is highly probable that 'Kibi' is a wabisuke camellia of 'Tarokaja' origin.

'Tarokaja' has been loved as a horticultural cultivar for at least 400 years, and its origins have been discussed for a long time. In this study, we investigated variations in the at $\mathrm{I}-a t p \mathrm{H}$ region of chloroplast DNA for a wide variety of Camellia species in our collection and found C.pitardii var. pitardii to be the maternal origin of 'Tarokaja'. Moreover, we verified the origins of a number of other wabisuke and the related cultivars. We will continue the genomic analysis with newly-obtained materials. Sakata et al. (1981) suggested a relationship between 'Tarokaja' and C. saluenensis based on their similarity of anthocyanin compositions. Now we are conducting chemotaxonomical analysis of anthocyanin and its related compounds between 'Tarokaja' and C. pitardii var. pitardii. We expect that these performances could support our conclusion or yield novel knowledge about 'Tarokaja' origin.

\section{Literature Cited}

Chang, H. T. and B. Bartholomew. 1984. Camellias. B. T. Batsford Ltd., London.

Gao, J., C. R. Parks and Y. Du. 2005. Collected species of the 
genus Camellia an illustrated outline. Zhejiang Science and Technology Press, Hangzhou.

Kitamura, S. 1952. The longlived horticultural varieties of Camelliae in Kyoto, Japan. Acta Phytotax. Geobot. 14: 115117 (In Japanese).

Kitamura, S. 1970. Uraku tsubaki no shozoku. Acta Phytotax. Geobot. 24: 173-174 (In Japanese).

Kirino, S. 1986. Chaseki no hana. Tsubaki to wabisuke (In Japanese). Bunka-shuppan-kyoku, Tokyo.

Makino, T. 1910. Observations on the flora of Japan. Bot. Mag., Tokyo 24: 71-84.

Nakai, T. 1950. On Camellia japonica, C. sasanqua and tea-plants. Natural Science and Museums 17: 1-17 (In Japanese).

Palmer, J. D. 1987. Chloroplast DNA evolution and biosystematic uses of chloroplast DNA variation. Am. Nat. 130: S6-S29.

Sakata, Y., S. Nagayoshi and K. Arisumi. 1981. Studies on the flower colours in the Camellia. II. On the anthocyanin constitution in the cultivars of C.japonica, C.japonica subsp. rusticana, C. sasanqua, C. hiemalis, C. vernalis and C. wabisuke. Mem. Fac. Agr. Kagoshima Univ. 17: 79-94.

Sealy, J. R. 1958. A revision of the genus camellia. The Royal Horticultural Society, London.

Tanaka, T., S. Kirino, N. Hakoda, K. Fujieda and T. Mizutani. 2001. Studies on the origin of Camellia wabiske. Proc. Sch. Agric. Kyushu Tokai Univ. 20: 1-7.

Tanikawa, N., T. Onozaki, M. Nakayama and M. Shibata. 2008. PCR-RFLP analysis of chloroplast DNA variations in the atpI-atpH spacer region of the genus Camellia. J. Japan. Soc. Hort. Sci. 77: 408-417.

Tsumura, Y., T. Kawahara, R. Wickneswari and K. Yoshimura. 1996. Molecular phylogeny of Dipterocarpaceae in Southeast Asia using RFLP of PCR-amplified chloroplast genes. Theor. Appl. Genet. 93: 22-29.

Yokoyama, S. and S. Kirino. 2005. Nihon no chinka (In Japanese). Tankosha Publishing Co., Ltd., Kyoto. 